K A N D A I

\begin{tabular}{|l|l|r|}
\hline Volume 16 & No. 1, Mei 2020 & Halaman 63-76 \\
\hline
\end{tabular}

\title{
ELEMENTARY SCHOOL TEACHERS ABILITY IN WRITING INDONESIAN LANGUAGE SENTENCES STRUCTURE (Kemampuan Guru Sekolah Dasar dalam Menulis Struktur Kalimat Bahasa Indonesia)
}

\author{
Apri Damai Sagita Krissandi \\ Faculty of Teacher Training and Education, Sanata Dharma University \\ Jalan Afandi Gejayan, Mrican, Yogyakarta, Indonesia \\ E-mail: apridamai@gmail.com \\ (Diterima: 23 Januari 2019; Direvisi: 13 Mei 2019; Disetujui: 7 Mei 2020)
}

\begin{abstract}
Abstrak
Penelitian ini bertujuan mendeskripsikan kemampuan menulis guru SD Kabupaten Mahakam Ulu dalam menulis struktur kalimat bahasa Indonesia. Penelitian ini merupakan penelitian kualitiatif deskriptif. Strategi pengumpulan data menggunakan survei. Subjek penelitian ini terdiri atas 20 orang guru SD Kabupaten Mahakan Ulu. Instrumen penelitian berupa soal. Instrumen soal berupa perintah membuat tiga kalimat dengan struktur: (1) S-P-O; (2) S-P-O-K; (3) K-S-P-O. Keabsahan data diperoleh dengan menggunakan triangulasi. Hasil penelitian menunjukkan bahwa kemampuan menulis guru-guru Mahakam Ulu, Kalimantan Timur masih tergolong kurang. Hal ini dapat dilihat dari kesesuaian kalimat-kalimat yang diproduksi dengan instruksi yang diminta. Kalimat yang sesuai instruksi sebanyak 36,7\%, sedangkan persentase kalimat yang tidak sesuai dengan instruksiberjumlah 63,3\%. Persentase kesesuaian kalimat dengan pola (1) adalah 55\%, sedangkan kalimat yang tidak sesuai dengan pola sebanyak 45\%; persentase kesesuaian kalimat yang sesuai dengan pola (2) adalah 30\%, sedangkan yang tidak sesuai adalah $70 \%$; persentase kesesuaian kalimat yang sesuai dengan pola (3) berjumlah 25\%, sedangkan yang tidak sesuai berjumlah 75\%. Kesalahan yang dilakukan para guru meliputi kesalahan fungsi objek, kesalahan fungsi keterangan, kesalahan fungsi pelengkap, dan 4) kesalahan tanda baca, kata depan, dan diksi.
\end{abstract}

Kata-kata kunci: kemampuan, menulis, kalimat

\section{Abstract}

This research aims to describe the Mahakam Ulu District elementary school teachers ability in writing sentence structure of Indonesian language. This research is adescriptive qualitative research. The subject of this study consisted of 20 elementary school teachers in Mahakan Ulu District. The data were collected by surveys. The instrument was in the form of an instruction to make three sentences with structure of: 1) $S-P-O$; 2) $S-P-O-K$; 3) $K-S-P-$ $O$. The data validity was obtained trough triangulation. The results show that the writing ability of teachers in Mahakam Ulu, East Kalimantan is still lacking. This can be seen from the conformity of the sentences produced with the instructions given. The sentences that correspond to the instructions are $36.7 \%$, while the percentage of sentences that do not correspond to the instructions is $63.3 \%$. The instruction is to make sentences with $S-P-O, S$ $P-O-K$, and $K-S-P-O$ patterns. Sentences correspond to the $S-P-O$ pattern are $55 \%$, while the percentage of sentences that do not correspond to the S-P-O pattern is $45 \%$. The sentences correspond to the $S-P-O-K$ pattern are $30 \%$, while the sentences that do not correspond to the $\mathrm{S}-\mathrm{P}-\mathrm{O}-\mathrm{K}$ pattern are $70 \%$. The sentences correspond to the $\mathrm{K}-\mathrm{S}-\mathrm{P}-\mathrm{O}$ pattern are $25 \%$, while the sentences that do not correspond to theK-S-P-O pattern are 75\%. Errors made by teachers are: 1) errors in objectfunction; 2) errors in adverbfunction; 3) errors in complementfunction; and 4) errors in punctuations, prepositions, and dictions. Keywords: ability, writing, sentences 
DOI: 10.26499/jk.v16il.1260

How to cite: Krissandi, A.D.S (2020). Elementary school teachers ability in writing Indonesia language sentences structure. Kandai, 16(1), 63-76 (DOI: 10.26499/jk.v16i1.1260)

\section{INTRODUCTION}

Teachers are the most dominant factor in the educational process and in the teaching and learning process (Sugiyono, 2002). Furthermore, the teachers are one of the educators who are theoretically representatives of the educators (Sulistiyono, 2014). According to Law Number 14 of 2005, ateacher is a professional educator who has a role in developing students fully through learning, which means thatindirectly the teachers must have an understanding in writing proper Indonesian sentences conform to structure and sentence patterns. Understanding the structure and sentence patterns is very important for teachers, especially elementary school teachers because according to Law no 20 of 2003, primary education is an education level implemented to develop the basic knowledge, abilities, and skills needed by students for the next level. One form of ability that needs to be developed in order to demonstrate teacher professionalism as an academic community is the writing ability (Riswanda, 2016).

Mahakam Ulu District is one of the new districts in the province of East Kalimantan, Indonesia. The legal basis for the establishment of Mahakam Ulu District is Law Number 2 of 2013 (Indonesia, 2013). As a new district, Mahakam Ulu District is included in the category of underdeveloped regions, including in the education field. This is shown from the interviews conducted to 20 respondents, in which the education level of the elementary school teachers is mostly at the high school level, only a small percentage of teachers who have a qualification obtained from Open
University. Teachers as the spearhead of education are the determinants of education quality in an area. As explained, the writing ability is very needed by the teachers in teaching students the habit of writing proper Indonesian sentences conform to the structure and sentence patterns of Indonesian language (Suyatinah, 2005). Therefore, this research aims to describe the ability of the Mahakam Ulu teachers in writing simple sentences conform to proper structure of Indonesian language. The simple sentence is chosen because it can represent a person's basic writing ability.

\section{THEORETICAL FRAMEWORK}

Writing is a manifestation form of the language skills that isthe most latter being mastered by language learners. Writing is an activity in an effort to convey ideas, thoughts, and feelings in written form so that readers can understand it. (Brown, 2007) stated that writing ability is skills in deciding what to write, how to write things, and the power to place written ideas in order to be accepted by others or readers. The success of the language as a communication tool cannot be separated from the development of communicative competence of the language usage (Mustadi, 2014).

One of the rules in language is syntax. Syntax is a part of grammar that study the basics and process of forming sentences in a language (Keraf, 1984). Syntax has several aspects of discussion, one of them is structure and sentence patterns. Understanding the rules of grammar, form, and structure of sentence is important for teacher to enable them to 
teach writing proper Indonesian sentences.

\section{RESEARCH METHOD}

This research isa descriptive qualitative research which aimsto describe the ability of Mahakam Ulu Elementary School Teachers in writing proper sentence structure in Indonesian language. This research was conducted in Yogyakarta when Mahakam Ulu teachers attended training at Sanata Dharma University in 2017. The subject of this study consisted of 20 teachers of Mahakam Ulu District from various elementary schools. The teachers were chosen as the subject of research because, based on researches knowledge, there had never been any research on those teachers' writing ability. The elementary school institutions where the respondents come from varies, covering various sub-districts in Mahakam Ulu Districtand is presented in Table 1.

Table 1. Distribution of Respondents School Institutions

\begin{tabular}{|c|c|c|}
\hline No. & $\begin{array}{c}\text { Elementary School } \\
\text { Location }\end{array}$ & $\begin{array}{c}\text { Number of } \\
\text { Respondents / } \\
\text { Resource } \\
\text { Persons }\end{array}$ \\
\hline 1. & $\begin{array}{l}\text { SDN } 02 \text { Muara Ratah, } \\
\text { Muara Ratah }\end{array}$ & 1 Teacher \\
\hline 2. & $\begin{array}{l}\text { SDN } 002 \text { Datah Bilang, } \\
\text { Kecamatan Long } \\
\text { Hubung }\end{array}$ & 1 Teacher \\
\hline 3. & $\begin{array}{l}\text { SDN } 003 \text { Long } \\
\text { Penaneh, Tiong Arong }\end{array}$ & 1 Teacher \\
\hline 4. & $\begin{array}{l}\text { SDN } 008 \text { Mamahak } \\
\text { Besar, Kecamatan Long } \\
\text { Bagun }\end{array}$ & 2 Teachers \\
\hline 5. & $\begin{array}{l}\text { SDN } 003 \text { Long Tuyoq, } \\
\text { Kecamatan Long } \\
\text { Pahangai }\end{array}$ & 1 Teacher \\
\hline 6. & $\begin{array}{l}\text { SDN } 005 \text { Long Lunuk, } \\
\text { Kecamatan Long } \\
\text { Pahangai }\end{array}$ & 1 Teacher \\
\hline 7. & $\begin{array}{l}\text { SDN } 007 \text { Mamahak } \\
\text { Teboq, Kecamatan } \\
\text { Long Hubung }\end{array}$ & 1 Teacher \\
\hline 8. & $\begin{array}{l}\text { SDN } 011 \text { Long Hurai, } \\
\text { Kecamatan Long Bagun }\end{array}$ & 1 Teacher \\
\hline
\end{tabular}

\begin{tabular}{|c|c|c|}
\hline & $\begin{array}{l}\text { SDN } 004 \text { Noha Silat, } \\
\text { Kecamatan Long Apari }\end{array}$ & 1 Teacher \\
\hline 10. & $\begin{array}{l}\text { SDN } 004 \text { Datah Bilang } \\
\text { Ulu, Kecamatan Long } \\
\text { Hubung }\end{array}$ & 2 Teachers \\
\hline 11. & $\begin{array}{l}\text { SDN } 003 \text { Long Bagun } \\
\text { Ilir }\end{array}$ & 1 Teacher \\
\hline 12. & $\begin{array}{l}\text { SDN } 002 \text { Ujoh Bilang, } \\
\text { Kecamatan Long Bagun }\end{array}$ & 2 Teachers \\
\hline 13. & $\begin{array}{l}\text { SDN } 001 \text { Laham, } \\
\text { Kecamatan Laham }\end{array}$ & 1 Teacher \\
\hline 14. & $\begin{array}{l}\text { SDN } 002 \text { Long } \\
\text { Pahangai }\end{array}$ & 1 Teacher \\
\hline 15. & $\begin{array}{l}\text { SDN } 001 \text { Tiong Bu'u, } \\
\text { Kecamatan Long Apari }\end{array}$ & 1 Teacher \\
\hline 16. & $\begin{array}{l}\text { SDN } 001 \text { Long } \\
\text { Hubung, Kecamatan } \\
\text { Long Hubung }\end{array}$ & 1 Teacher \\
\hline & Total & 20 Teacher \\
\hline
\end{tabular}

. The education level of elementary school teachers in this research is presented in Table 2.

Table 2. Respondents' education data

Teachers' Respondent education data

\begin{tabular}{ll} 
SPG (Teacher Education & 5 Teachers \\
Institution equal to High & \\
School level) & \\
High School & 9 Teachers \\
SMEA/Vocational High & 2 Teachers \\
School & \\
$\begin{array}{l}\text { Bachelor degree fromOpen } \\
\text { University }\end{array}$ & 4 Teachers \\
\hline
\end{tabular}

Data collection technique used were writing tests and interview. The question instrument in the form of an instruction to make three sentences with Subjek/S (Subject), Predikat/P (Predicate), Objek/O (Object), Keterangan $/ \mathrm{K}$ (Adverb) with the structure of S-P-O, S-P-O-K, and K-S-P$\mathrm{O}$. To determine the validity of the data, data verification criteria were needed in the form of criteria for the degree of trust. Validation used to maintain this credibility was triangulation. The analysis carried out in this research consisted of three activities that run simultaneously which were: (1) data reduction, the process of selecting, 
focusing, attention to simplifying, abstracting, and transforming rough data from written records in the field; (2) data presentation, the presentation of information that has been arranged which was possibly provide conclusions; and (3) drawing conclusions/verification, in this activity the researcher searched for meaning, records sequences, and patterns from the beginning of data collection.

\section{DISCUSSION}

This research focused on looking at the ability of Mahakam Ulu Elementary School teachers in writing proper simple sentence structures in Indonesian language.. Based on the question sheet, the answers are shown in Table 3.

Table 3. Sentences Made by Respondents

\begin{tabular}{|c|c|c|c|}
\hline Res & \multicolumn{3}{|c|}{ Instruction: Make a sentence with the following pattern! } \\
\hline $\begin{array}{l}\text { dent } \\
\text { numb } \\
\text { er }\end{array}$ & S-P-O & S-P-O-K & K-S-P-O \\
\hline \multicolumn{4}{|c|}{ Answer } \\
\hline 1 & $\begin{array}{l}\text { Ani pergi kepasar } \\
\text { (Ani goes to the market) }\end{array}$ & $\begin{array}{l}\text { Ani pergi kepasar membeli } \\
\text { sayur-sayuran. } \\
\text { (Ani goes to market buying } \\
\text { vegetables) }\end{array}$ & $\begin{array}{l}\text { Sayuran bayak terdapat di } \\
\text { Pasar Senin. } \\
\text { (Vegetables are found many } \\
\text { inSenin Market.) }\end{array}$ \\
\hline 2 & $\begin{array}{l}\text { Agus memancing di } \\
\text { sungai } \\
\text { (Agus fishes in the river) }\end{array}$ & $\begin{array}{l}\text { Agus memancing di sungai } \\
\text { dan mendapat ikan. } \\
\text { (Agus fishesin the river and } \\
\text { gets fish.) }\end{array}$ & $\begin{array}{l}\text { Ikan ini didapat oleh agus yang } \\
\text { memancing di sungai } \\
\text { (This fish is got by Agus who is } \\
\text { fishing in the river) }\end{array}$ \\
\hline 3 & $\begin{array}{l}\text { Saya ingin pergi ke pasar } \\
\text { (I want to go to the } \\
\text { market) }\end{array}$ & $\begin{array}{l}\text { Mereka pergi kepantai untuk } \\
\text { berenang } \\
\text { (They go to the beach to } \\
\text { swim) }\end{array}$ & $\begin{array}{l}\text { Agar dapat tidur nyenyak, Pak } \\
\text { Nsir membeli obat lelap } \\
\text { diapotek } \\
\text { (In order to be able to sleep } \\
\text { well, Mr. Nsir buyssleeping } \\
\text { pills in the pharmacy) }\end{array}$ \\
\hline 4 & $\begin{array}{l}\text { Agus membeli sebuah } \\
\text { sepatu } \\
\text { (Agus buys a shoe) }\end{array}$ & $\begin{array}{l}\text { Budi menunjungi Candi } \\
\text { Borobudur pada hari Minggu } \\
\text { (Budi visits Borobudur } \\
\text { Temple on Sunday) }\end{array}$ & $\begin{array}{l}\text { Pada tanggal } 02 \text { Agustus } 2015 \\
\text { Para Guru magang melakukan } \\
\text { studi budaya ke Candi } \\
\text { Prambanan } \\
\text { (On } 2 \text { August } 2015 \text { the } \\
\text { apprentice teachers conducted a } \\
\text { cultural study at Prambanan } \\
\text { Temple) }\end{array}$ \\
\hline 5 & $\begin{array}{l}\text { Borobudur tujuan wisata } \\
\text { saya } \\
\text { (Borobudur is my vacation } \\
\text { destination) }\end{array}$ & $\begin{array}{l}\text { Mereka berangkat ke Candi } \\
\text { Prambanan pada sore hari } \\
\text { (They go to Prambanan } \\
\text { Temple in the afternoon) }\end{array}$ & $\begin{array}{l}\text { Pada malam hari mereka } \\
\text { memakai lampu senter. } \\
\text { (At night they use flashlights.) }\end{array}$ \\
\hline 6 & $\begin{array}{l}\text { Ali menendang bola. } \\
\text { (Ali kicks the ball.) }\end{array}$ & $\begin{array}{l}\text { Ali menendang bola ke } \\
\text { gawang. } \\
\text { (Ali kicks the ball into the } \\
\text { goal.) }\end{array}$ & $\begin{array}{l}\text { tidak dijawab } \\
\text { (No answer) }\end{array}$ \\
\hline 7 & $\begin{array}{l}\text { Ani memukul bola } \\
\text { (Ani hits the ball) }\end{array}$ & $\begin{array}{l}\text { Adi bermain bola di halaman. } \\
\text { (Adi plays the ball in the } \\
\text { yard.) }\end{array}$ & $\begin{array}{l}\text { Ani membantu ibu } \\
\text { membersihkan rumah. } \\
\text { (Ani helps the mother clean the } \\
\text { house.) }\end{array}$ \\
\hline
\end{tabular}




\begin{tabular}{|c|c|c|c|}
\hline 8 & $\begin{array}{l}\text { Bunga meraih gelar } \\
\text { sarjananya di Universitas } \\
\text { Sanata Dharma. } \\
\text { (Bunga gother bachelor } \\
\text { degree at Sanata Dharma } \\
\text { University.) }\end{array}$ & $\begin{array}{l}\text { Ririn melakukan studi budaya } \\
\text { ke Candi Badut yang terletak } \\
\text { di Jawa Timur. } \\
\text { (Ririn conducts a cultural } \\
\text { study at Badut Temple } \\
\text { located in East Java.) }\end{array}$ & $\begin{array}{l}\text { Tidak dijawab } \\
\text { (No answer) }\end{array}$ \\
\hline 9 & $\begin{array}{l}\text { Adik minum susu } \\
\text { (Sister is drinking milk) }\end{array}$ & $\begin{array}{l}\text { Ibu sedang memasak nasi } \\
\text { (Mother is cooking rice) }\end{array}$ & $\begin{array}{l}\text { Tadi pagi Ibu memasak nasi } \\
\text { didapur } \\
\text { (This morning mother cooked } \\
\text { rice in the kitchen) }\end{array}$ \\
\hline 10 & $\begin{array}{l}\text { Saya memasak nasi. } \\
\text { (I cook rice.) }\end{array}$ & $\begin{array}{l}\text { Saya sedang belajar dikamar. } \\
\text { (I am studying in the room.) }\end{array}$ & $\begin{array}{l}\text { Kemarin Tina tidak turun } \\
\text { kesekolah karena sakit. } \\
\text { (Yesterday Tina didn't goto } \\
\text { school because of sickness.) }\end{array}$ \\
\hline 11 & $\begin{array}{l}\text { Adik sedang makan kue. } \\
\text { (Sister is eating cake.) }\end{array}$ & $\begin{array}{l}\text { Adik sedang makan kue bolu. } \\
\text { (Sister is eating sponge cake.) }\end{array}$ & $\begin{array}{l}\text { Kue bolu sedang dimakan adik. } \\
\text { (The sponge cake is being eaten } \\
\text { by sister.) }\end{array}$ \\
\hline 12 & $\begin{array}{l}\text { Saya makan nasi } \\
\text { (I eat rice) }\end{array}$ & $\begin{array}{l}\text { Kakak bermain bola di } \\
\text { halaman } \\
\text { (Sister plays ball in the yard) }\end{array}$ & $\begin{array}{l}\text { Tadi pagi Ibu memasak nasi } \\
\text { (This morning mother cooked } \\
\text { rice) }\end{array}$ \\
\hline 13 & $\begin{array}{l}\text { Ima memasak nasi. } \\
\text { (Ima cooks rice.) }\end{array}$ & $\begin{array}{l}\text { Ima memasak nasi di dapur. } \\
\text { (Ima cooks rice in the } \\
\text { kitchen.) }\end{array}$ & $\begin{array}{l}\text { Jogja merupakan tujuan wisata. } \\
\text { (Jogja is a tourist destination. }\end{array}$ \\
\hline 14 & $\begin{array}{l}\text { Ibu sedang pergi ke pasar. } \\
\text { (Motheris going to the } \\
\text { market.) }\end{array}$ & $\begin{array}{l}\text { Ratna sedang membaca buku } \\
\text { Bahasa Indonesia } \\
\text { (Ratna is reading an } \\
\text { Indonesian language book) }\end{array}$ & $\begin{array}{l}\text { Bapak bepergian bersama ibu } \\
\text { (Father travels with mother) }\end{array}$ \\
\hline 15 & $\begin{array}{l}\text { Anita membaca koran } \\
\text { (Anita reads newspaper) }\end{array}$ & $\begin{array}{l}\text { Anita membaca koran di } \\
\text { halaman rumah. } \\
\text { (Anita reads the newspaper in } \\
\text { the veranda) }\end{array}$ & $\begin{array}{l}\text { Di halaman rumah Anita } \\
\text { membaca koran } \\
\text { (In the veranda Anitareads the } \\
\text { newspaper) }\end{array}$ \\
\hline 16 & $\begin{array}{l}\text { Tidak menjawab } \\
\text { (No answer) }\end{array}$ & $\begin{array}{l}\text { Tidak menjawab } \\
\text { (No answer) }\end{array}$ & $\begin{array}{l}\text { Tidak dijawab } \\
\text { (No answer) }\end{array}$ \\
\hline 17 & $\begin{array}{l}\text { Saya membaca buku } \\
\text { (I read book) }\end{array}$ & $\begin{array}{l}\text { Saya menonton TV di kamar } \\
\text { (I watch TV in the room) }\end{array}$ & $\begin{array}{l}\text { Di lapangan sepak bola kami } \\
\text { memungut sampah yang } \\
\text { berhamburan } \\
\text { (At the soccer field we pick up } \\
\text { scattered garbage) }\end{array}$ \\
\hline 18 & $\begin{array}{l}\text { Ayah sedang duduk. } \\
\text { (Daddy is sitting.) }\end{array}$ & $\begin{array}{l}\text { Ayah sedang duduk di teras. } \\
\text { (Daddy is sitting on the } \\
\text { terrace.) }\end{array}$ & $\begin{array}{l}\text { Kemarin ayah mencangkul di } \\
\text { sawah. } \\
\text { (Yesterday my father hoeed in } \\
\text { the field.) }\end{array}$ \\
\hline 19 & $\begin{array}{l}\text { Saya mau menonton } \\
\text { Televisi } \\
\text { (I want to watch } \\
\text { television) }\end{array}$ & $\begin{array}{l}\text { Anak-anak itu bermain di } \\
\text { halaman sekolah } \\
\text { (Those children play on the } \\
\text { school yard) }\end{array}$ & $\begin{array}{l}\text { Sekolah tersebut memperoleh } \\
\text { sebuah penghargaan berupa } \\
\text { piagam } \\
\text { (That school received an award } \\
\text { in the form of a charter) }\end{array}$ \\
\hline 20 & $\begin{array}{l}\text { Farel membaca buku di } \\
\text { perpustakaan } \\
\text { (Farel reads book in the } \\
\text { library) }\end{array}$ & $\begin{array}{l}\text { Ani rajin belajar diruangan } \\
\text { depan. } \\
\text { (Ani studiesdiligently in the } \\
\text { front room.) }\end{array}$ & $\begin{array}{l}\text { Keindahan dapat dirasakan } \\
\text { apabila rumah kita selalu } \\
\text { bersih. } \\
\text { (Beauty can be felt if our house } \\
\text { is always clean) }\end{array}$ \\
\hline
\end{tabular}


The respondents' sentences are rewritten without any changes, in term of spelling, letters, and punctuation. Based on the answers, the sentences that correspond to the instruction are marked with a black block. The sentences that correspond to the instruction are 22 sentences. Sentences that do not correspond to the instruction are 38 sentences. The percentage of sentences that correspond and not correspond to instruction is presented in Figure 1.

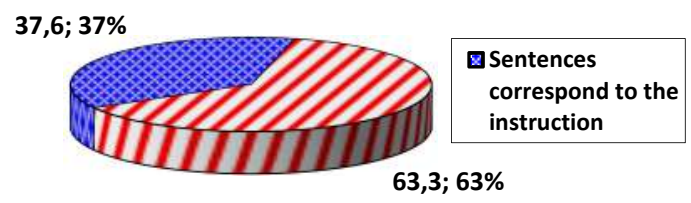

Figure 1. Diagram of the Percentage of Sentences that Correspond and Not Correspond to the Instruction

The percentage of sentences that do not correspond to the instruction is much bigger than the percentage of sentences that correspond to the instruction. The percentage is presented in Figure 2.

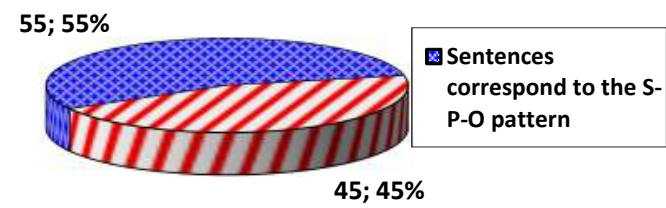

Figure 2. Diagram of the Percentage of Sentences that Correspond and Not Correspond to the S-P-O pattern

The percentage of sentences that correspond and not correspond to the S$\mathrm{P}-\mathrm{O}-\mathrm{K}$ pattern is presented in Figure 3.

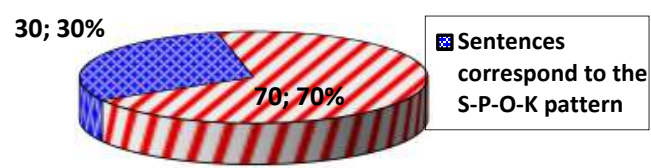

Figure 3. Diagram of the Percentage of Sentences that Correspond and Not Correspond to the S-P-O-K pattern
The percentage of the number of sentences that not correspond to the S-P$\mathrm{O}-\mathrm{K}$ pattern is much bigger than the one that correspond to the S-P-O-K pattern. The percentage of sentences that correspond and not correspond to the K$\mathrm{S}-\mathrm{P}-\mathrm{O}$ pattern is presented in Figure 4.

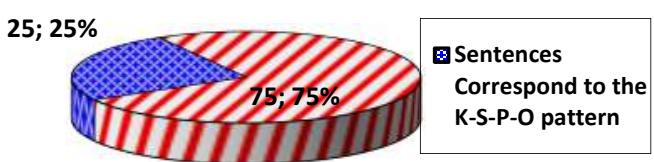

Figure 4. Diagram of the Percentage of Sentences that Correspond and Not Correspond to the K-S-P-O pattern

\section{DISCUSSION}

Mastery of structures and sentence patterns is very important for teachers, especially elementary school teachers. Delivery of concepts and ideas related to the learning material presented to students needs to be supported by an understanding on vocabulary and sentence structure. The teachers' mastery on the sentence structure indirectly will make it easier for them to provide habituation in students, especially in writing sentences conform to Indonesian language rules. (Nurgiantoro, 2005) stated that children's language development is in line with the development of intellectual and personality aspects. By habituating students, especially writing in accordance with the development of intellectual and personality aspects, it is very possible for a person to be skilled in language both receptively and expressively.

In the elementary school competency standard of Indonesian subject on the writing aspect, it is expected that students have the competence to do various types of writing activities to express thoughts, feelings, and information in the form of 
simple essays, instructions, letters, announcements, dialogues, forms, speech text, reports, summaries, paraphrases, and also various literary works for children in the form of stories, poems, and rhymes. Indeed, if this is what the government demands, teachers must master writing skills, especially the ability to write sentence structures. Based on the results of the data obtained, the number of sentences that correspond to the instructions is only $36.7 \%$. This shows low result. In other words, the ability of the Mahakam Ulu teachers to write the sentences structure in Indonesian language shows low criteria. The low ability in writing the proper sentence structure is due to the mistakes made by teachers in writing sentences correspond to the instructed sentence patterns functions. This is very concerning. One form of ability that needs to be developed in order to show teachers professionalism as an academic community is the writing ability (Riswanda, 2016). The research results show that teachers professionalism tends to be low.

Error function of sentence patterns written by respondents can be analyzed in a grammatical structure. Grammatical structure analysis on the sentence produces a description of the function of the subjek (subject), predikat (predicate), objek (object) and other functions. In addition to having to pay attention to the function limit itself one must also pay attention to the characteristics of each grammatical structure in the sentence (Suhardi and Setiawan, 1997). Finoza (2008) stated that the sentence element is a grammatical structure in sentences which in old grammar books are commonly called jabatan kata (word positions) and are now called peran kata (word roles), i.e ubyek/S (Subject), Predikat/P (Predicate), Objek/O (Object), Pelengkap/Pel (complement), and Keterangan $/ \mathrm{K}$ (Adverb). The standard sentence consists of at least two elements, $\mathrm{S}$ and $\mathrm{P}$. Other elements $(\mathrm{O}$, Pel, and Ket) can be required to present, not required to present, or must not be presented in a sentence.

Errors made by teachers in writing sentence structures can be classified into: 1. Error in objek function; 2. Error in keterangan function; 3 . Error in pelengkap function; Another mistakes made by the teachers are spelling, punctuation, and diction. More details can be explained as follows:

\section{Error in Objek Function}

Objek (object) is not mandatory element in sentences. Its existence is generally located after a predicatecategorized as transitive verb. Objek is sentences constituent that its presence is demanded by a transitive verb in an active sentence. The location is always after predicate. Objek is usually nomina (noun) or frasa nomina (noun phrase). In addition to units in the form of nomina and frasa nomina, objek constituent can also be clauses (multilevel compounds of object expansion). Objek in the transitive active sentence will be the subjectif the sentence is made into a passive one. Broadly speaking the characteristics of objek are: 1. in the form of nouns; 2. not preceded by the preposition; 3 . following directly behind the transitive predicate; 4. the answers on what or who that located behind the transitive predicate; 5 . occupying the subjectfunction if the sentence is a passive one. 
Table 4. Objek Function Errors in Sentences

\begin{tabular}{|c|c|c|c|c|c|}
\hline \multicolumn{6}{|c|}{ Instruction and Respondents' Answers } \\
\hline No. & S-P-O Pattern & No. & S-P-O-K Pattern & No. & K-S-P-O Pattern \\
\hline & Errors 1 & & Errors 2 & & Errors 3 \\
\hline 1 & Ani pergi kepasar (S-P-K) & 5 & $\begin{array}{l}\text { Saya sedang belajar } \\
\text { dikamar. (S-P-K) }\end{array}$ & 9 & $\begin{array}{l}\text { Sayuran bayak terdapat di } \\
\text { Pasar Senin. (S-P-K) }\end{array}$ \\
\hline 2 & $\begin{array}{l}\text { Agus memancing di sungai } \\
\text { (S-P-K) }\end{array}$ & 6 & $\begin{array}{l}\text { Ayah sedang duduk di } \\
\text { teras. (S-P-K) }\end{array}$ & 10 & $\begin{array}{l}\text { Bapak bepergian bersama } \\
\text { ibu (S-P-K) }\end{array}$ \\
\hline 3 & $\begin{array}{l}\text { Saya ingin pergi ke pasar } \\
(\mathrm{S}-\mathrm{P}-\mathrm{K})\end{array}$ & 7 & $\begin{array}{l}\text { Anak-anak itu bermain di } \\
\text { halaman sekolah (S-P-K) }\end{array}$ & 11 & $\begin{array}{l}\text { Kemarin ayah mencangkul } \\
\text { di sawah. (K-S-P-K) }\end{array}$ \\
\hline 4 & $\begin{array}{l}\text { Ibu sedang pergi ke pasar. } \\
\text { (S-P-K) }\end{array}$ & 8 & $\begin{array}{l}\text { Ani rajin belajar diruangan } \\
\text { depan. }(\mathrm{S}-\mathrm{P}-\mathrm{K})\end{array}$ & 12 & $\begin{array}{l}\text { Keindahan dapat dirasakan } \\
\text { apabila rumah kita selalu } \\
\text { bersih. (S-P-K) }\end{array}$ \\
\hline
\end{tabular}

The 12 sentences above do not have objek, while the instruction given is to make sentences using the S-P-O, S-P$\mathrm{O}-\mathrm{K}$, and K-S-P-O patterns. Each respondent was instructed to make three sentences which all three must have objek. Table 4 shows that the respondents are wrong in the objekfunction, that isthe objek function is replaced by keterangan function. The instruction given was to make sentences with the S-P-O pattern, but respondents made S-P-K pattern. For example is sentences number 1 and 2 below.

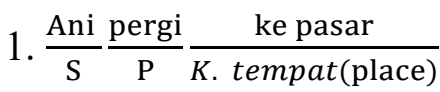

2. $\frac{\text { Agus memancing di sungai }}{\mathrm{S}} \frac{\mathrm{d}}{\mathrm{P}}$

The two examples above show respondents' errors in identifying objek function. Respondents have misconceptions between objek and keterangan. Respondents do not well understand the function of objek and keterangan in Indonesian sentences. Similar errors appear in the sentences in table 4.

Another error that appears from the sentences in table 4 is the phrase concept that can occupy certain functions. Some respondents assume that the function of sentence patterns is based on words. This can be seen from the following examples.

1. $\frac{\text { Saya }}{\mathrm{S}} \frac{\text { sedang belajar }}{\mathrm{P}} \frac{\mathrm{di} \text { kamar }}{\text { K.tempat }}$

2. $\frac{\text { Ayah }}{\mathrm{S}} \frac{\text { sedang duduk }}{\mathrm{P}} \frac{\text { di teras }}{\text { K.tempat }}$

The instruction given to the respondents was to make sentences with the S-P-O-K pattern, but the respondents' made sentence with the $\mathrm{S}$ P-K pattern. This shows misconceptionaboutwords and phrases. Based on interviews with respondents, it was said that the word "sedang" in the example above was considered to occupy the predicatefunction and the word "duduk" as an objek. This errors occurs because the respondent's lack in understanding the concepts of words and phrases.Some respondents do not understand that phrases can occupy a particular function in the sentence structure or pattern.

\section{Error in Keterangan Function}

Keterangan (adverb) is a further explanation in the pattern and arrangement of sentences. Keterangan explains how, when, and where the work was carried out. Keterangan can be in the form of information on places such 
as houses, schools, markets, roads, fields, offices, and so on. Keterangan of time such as, afternoon, night, daytime, dusk, etc. In addition, there are keterangan that adapts to the context of the sentence such as keterangan cara (method) such as, very quickly, more effectively, easier and so on.
Errors in the keterangan function made by the teachersare adding keterangan in the S-P-O sentence, not giving keterangan in the S-P-O-K sentence, and replacing the function of objek (O) with keterangan. The following is a summary of errors made by the resource people.

Table 5. Keterangan Function Errors in Sentences

\begin{tabular}{|c|c|c|c|c|c|}
\hline \multicolumn{6}{|c|}{ Instruction and Respondents' Answers } \\
\hline \multirow[t]{2}{*}{ No. } & S-P-O & No. & S-P-O-K & No. & K-S-P-O \\
\hline & Errors 1 & & Errors 2 & & Errors 3 \\
\hline \multirow[t]{6}{*}{1} & $\begin{array}{l}\text { Bunga meraih gelar } \\
\text { sarjananya di Universitas } \\
\text { Sanata Dharma. (S-P-O- } \\
\text { K) }\end{array}$ & 2 & $\begin{array}{l}\text { Mereka pergi kepantai } \\
\text { untuk berenang (S-P-K- } \\
\mathrm{K})\end{array}$ & 8 & $\begin{array}{l}\text { Agar dapat tidur nyenyak, Pak } \\
\text { Nsir membeli obat lelap } \\
\text { diapotek (K-S-P-O-K) }\end{array}$ \\
\hline & & 3 & $\begin{array}{l}\text { Mereka berangkat ke } \\
\text { Candi Prambanan pada } \\
\text { sore hari (S-P-K-K) }\end{array}$ & 9 & $\begin{array}{l}\text { Kemarin Tina tidak turun } \\
\text { kesekolah karena sakit. (K-S-P- } \\
\mathrm{K}-\mathrm{K} \text { ) }\end{array}$ \\
\hline & & 4 & $\begin{array}{l}\text { Ibu sedang memasak nasi } \\
(\mathrm{S}-\mathrm{P}-\mathrm{O})\end{array}$ & 10 & $\begin{array}{l}\text { Jogja merupakan tujuan wisata. } \\
\text { (S-P-Pel) }\end{array}$ \\
\hline & & 5 & $\begin{array}{l}\text { Adik sedang makan kue } \\
\text { bolu. (S-P-O) }\end{array}$ & 11 & $\begin{array}{l}\text { Sekolah tersebut memperoleh } \\
\text { sebuah penghargaan berupa } \\
\text { piagam (S-P-O) }\end{array}$ \\
\hline & & 6 & $\begin{array}{l}\text { Ratna sedang membaca } \\
\text { buku Bahasa Indonesia } \\
(\mathrm{S}-\mathrm{P}-\mathrm{O})\end{array}$ & 12 & $\begin{array}{l}\text { Ani membantu ibu } \\
\text { membersihkan rumah. (S-P-O- } \\
\text { K) }\end{array}$ \\
\hline & & 7 & $\begin{array}{l}\text { Ani pergi kepasar } \\
\text { membeli sayur-sayuran. } \\
\text { (S-P-K-K) (Majemuk) }\end{array}$ & & \\
\hline
\end{tabular}

There are some keterangan function errors in sentence pattern. In the first instruction, the respondents were asked to write sentence with the S-P-O pattern, but instead they added the $\mathrm{K}$ (keterangan) function. This shows that the respondents lack in understanding the keterangan function in which keterangan is not a must in a sentence. The next mistake, when the respondents were asked to make a sentence with the S-P-O-K pattern, the respondents actually wrote the sentence with the pattern of (S-P-K-K) and (S-P-O). S-P$\mathrm{K}-\mathrm{K}$ pattern error is in the sentence number 2 Mereka pergi kepantai untuk berenang (S-P-K-K); sentence number 3 Mereka berangkat ke Candi Prambanan pada sore hari (S-P-K-K). S-P-O pattern errors: sentence number $4 \mathrm{Ibu}$ sedang memasak nasi (S-P-O); Sentence number 5 Adik sedang makan kue bolu. (S-P-O); Ratna sedang membaca buku Bahasa Indonesia (S-P-O). The error shows that the respondents do not well understand the function of keterangan in the sentence.

The instruction was to make sentence with K-S-P-O pattern, but they wrote the sentence with keterangan function in it therefore the structure becomes K-S-P-O-K, for example: Agar dapat tidur nyenyak, Pak Nasir membeli obat lelap diapotek (K-S-P-O-K), in addition to the structural errors, there is also a misuse of preposition di-.In that 
sentence diapotek should be di apotek. Sentence number 9, Kemarin Tina tidak turun kesekolah karena sakit has a pattern of K-S-P-K-K, which did not complythe instruction given. In addition to sentence structure errors, there is also an error in the preposition ke-. In the sentence, it is written kesekolah, which should be ke sekolah. The diction selection in the sentence is also not right.Phrase tidak turunin the context of this sentence means tidak masuk.This case is influenced by the local language. Sentence number 10, Jogja merupakan tujuan wisata has the S-P-Pel sentence pattern which is not in accordance with the instruction given. In addition to the respondents not knowing the keterangan function, in the sentences there are also pelengkap function errors. The phrase of tujuan wisata in the sentence is pelengkap, not objek. Sentences number
11 and 12 also experience misuse of keterangan.

\section{Error in Pelengkap Function}

Pelengkap (complement) is a sentence element that complements other elements, to add or clarify meaning or keterangan. Pelengkap in a sentence functions the same as objek $(\mathrm{O})$, but the difference is that complement cannot be made or changed into subjek (S) when the sentence made into passive sentence. The pelengkap is usually located after the predicateor after the objek.

The use of pelengkap in a sentence is often confusing. Pelengkap is often reversed with objek functions. The error of this pelengkap function was also experienced by the respondents. Based on the data collected, there are 4 errors related to the pelengkap.

Table 6. Pelengkap Function Errors in Sentences

\begin{tabular}{|c|c|c|c|c|c|}
\hline \multicolumn{6}{|c|}{ Instruction and Respondents' Answers } \\
\hline No. & S-P-O & No. & S-P-O-K & No. & K-S-P-O \\
\hline & Error 1 & & Error 2 & & Error 3 \\
\hline 1 & $\begin{array}{l}\text { Borobudur tujuan wisata } \\
\text { saya (S-P-Pel) }\end{array}$ & 2 & $\begin{array}{l}\text { Adi bermain bola di } \\
\text { halaman. (S-P-Pel-K) }\end{array}$ & 4 & $\begin{array}{l}\text { Jogja merupakan tujuan } \\
\text { wisata. (S-P-Pel) }\end{array}$ \\
\hline & & 3 & $\begin{array}{l}\text { Kakak bermain bola di } \\
\text { halaman (S-P-Pel-K) }\end{array}$ & & \\
\hline
\end{tabular}

There is a lack of understanding from the respondents toward the instructions. The first instruction was to make sentences using the S-P-O pattern, the respondent answered with the S-PPel pattern (sentence number 1)which is a passive sentence. In passive sentences, generally the function after the predicateis pelengkap. The second instruction was to make a sentence with the S-P-O-K pattern, there was no instruction to add pelengkap function. The respondents answered with the S-P-
Pel-K pattern (sentences number 2 and $3)$. Sentences number 2 and 3 are incorrect as they usepredicatewithprefix ber-. Such predicate must be followed by pelengkap function. This is not in accordance with the instruction, in which to make sentence with the S-P-O-K pattern. The third instruction was to make sentence with the K-S-P-O pattern, the respondents answered with S-P-Pel pattern (sentence number 4). Respondents experienced misconceptions aboutthe function of the 
requested sentence pattern. This can be seen from the significant differences between instructions and answers.

\section{Errors in Punctuation, Prepositions, and Dictions}

In addition to errors in sentence patterns, mistakes made by the respondents included spelling and punctuation. An example is the use of period. Table 3 is the original data without additions and subtractions in terms of punctuation, letters, or word choices. It can be seen that there are 24 sentences that have correctperiod punctuation use from a total of 60 sentences made. This is shown in Table 7.

Table 7. Errors in Punctuation

\begin{tabular}{|c|c|c|c|}
\hline Res & \multicolumn{3}{|c|}{ Instruction: Make a sentence with the following pattern! } \\
\hline $\begin{array}{l}\text { pon } \\
\text { dents } \\
\text { numb } \\
\text { er }\end{array}$ & $\mathrm{S}-\mathrm{P}-\mathrm{O}$ & S-P-O-K & K-S-P-O \\
\hline \multicolumn{4}{|c|}{ Jawaban } \\
\hline 1 & Ani pergi kepasar & $\begin{array}{l}\text { Ani pergi kepasar membeli } \\
\text { sayur-sayuran. } \sqrt{ }\end{array}$ & $\begin{array}{l}\text { Sayuran bayak terdapat di Pasar } \\
\text { Senin. }\end{array}$ \\
\hline 2 & $\begin{array}{l}\text { Agus memancing di } \\
\text { sungai }\end{array}$ & $\begin{array}{l}\text { Agus memancing di sungai } \\
\text { dan mendapat ikan. } \sqrt{ }\end{array}$ & $\begin{array}{l}\text { Ikan ini didapat oleh agus yang } \\
\text { memancing di sungai }\end{array}$ \\
\hline 3 & $\begin{array}{l}\text { Saya ingin pergi ke } \\
\text { pasar }\end{array}$ & $\begin{array}{l}\text { Mereka pergi kepantai untuk } \\
\text { berenang }\end{array}$ & $\begin{array}{l}\text { Agar dapat tidur nyenyak, Pak } \\
\text { Nsir membeli obat lelap diapotek }\end{array}$ \\
\hline 4 & $\begin{array}{l}\text { Agus membeli sebuah } \\
\text { sepatu }\end{array}$ & $\begin{array}{l}\text { Budi menunjungi Candi } \\
\text { Borobudur pada hari Minggu }\end{array}$ & $\begin{array}{l}\text { Pada tanggal } 02 \text { Agustus } 2015 \\
\text { Para Guru magang melakukan } \\
\text { studi budaya ke Candi Prambanan }\end{array}$ \\
\hline 5 & $\begin{array}{l}\text { Borobudur tujuan } \\
\text { wisata saya }\end{array}$ & $\begin{array}{l}\text { Mereka berangkat ke Candi } \\
\text { Prambanan pada sore hari }\end{array}$ & $\begin{array}{l}\text { Pada malam hari mereka memakai } \\
\text { lampu senter. } \sqrt{ }\end{array}$ \\
\hline 6 & Ali menendang bola. $\sqrt{ }$ & $\begin{array}{l}\text { Ali menendang bola ke } \\
\text { gawang. } \sqrt{ }\end{array}$ & tidak dijawab \\
\hline 7 & Ani memukul bola & $\begin{array}{l}\text { Adi bermain bola di halaman. } \\
\sqrt{ }\end{array}$ & $\begin{array}{l}\text { Ani membantu ibu membersihkan } \\
\text { rumah. } \sqrt{ }\end{array}$ \\
\hline 8 & $\begin{array}{l}\text { Bunga meraih gelar } \\
\text { sarjananya di } \\
\text { Universitas Sanata } \\
\text { Dharma. } \sqrt{ }\end{array}$ & $\begin{array}{l}\text { Ririn melakukan studi budaya } \\
\text { ke Candi Badut yang terletak } \\
\text { di Jawa Timur. } \sqrt{ }\end{array}$ & Tidak dijawab \\
\hline 9 & Adik minum susu & Ibu sedang memasak nasi & $\begin{array}{l}\text { Tadi pagi Ibu memasak nasi } \\
\text { didapur }\end{array}$ \\
\hline 10 & Saya memasak nasi. $\sqrt{ }$ & $\begin{array}{l}\text { Saya sedang belajar dikamar. } \\
\sqrt{ }\end{array}$ & $\begin{array}{l}\text { Kemarin Tina tidak turun } \\
\text { kesekolah karena sakit. } \sqrt{ }\end{array}$ \\
\hline 11 & $\begin{array}{l}\text { Adik sedang makan } \\
\text { kue. } \sqrt{ }\end{array}$ & $\begin{array}{l}\text { Adik sedang makan kue bolu. } \\
\sqrt{ }\end{array}$ & Kue bolu sedang dimakan adik. $\sqrt{ }$ \\
\hline 12 & Saya makan nasi & $\begin{array}{l}\text { Kakak bermain bola di } \\
\text { halaman }\end{array}$ & Tadi pagi Ibu memasak nasi \\
\hline 13 & Ima memasak nasi. $\sqrt{ }$ & Ima memasak nasi di dapur. $\sqrt{ }$ & Jogja merupakan tujuan wisata. $\sqrt{ }$ \\
\hline
\end{tabular}




\begin{tabular}{clll}
\hline $\mathbf{1 4}$ & $\begin{array}{l}\text { Ibu sedang pergi ke } \\
\text { pasar. } \sqrt{ }\end{array}$ & $\begin{array}{l}\text { Ratna sedang membaca buku } \\
\text { Bahasa Indonesia }\end{array}$ & Bapak bepergian bersama ibu \\
\hline $\mathbf{1 5}$ & Anita membaca koran & $\begin{array}{l}\text { Anita membaca koran di } \\
\text { halaman rumah. } \sqrt{ }\end{array}$ & $\begin{array}{l}\text { Di halaman rumah Anita membaca } \\
\text { koran }\end{array}$ \\
\hline $\mathbf{1 6}$ & Tidak menjawab & Tidak menjawab & Tidak dijawab \\
\hline $\mathbf{1 7}$ & Saya membaca buku & Saya menonton TV di kamar & $\begin{array}{l}\text { Di lapangan sepak bola kami } \\
\text { memungut sampah yang } \\
\text { berhamburan }\end{array}$ \\
\hline $\mathbf{1 8}$ & Ayah sedang duduk. & Ayah sedang duduk di teras. & $\begin{array}{l}\text { Kemarin ayah mencangkul di } \\
\text { sawah. } \sqrt{ }\end{array}$ \\
\hline $\mathbf{1 9}$ & $\begin{array}{l}\text { Saya mau menonton } \\
\text { Televisi }\end{array}$ & $\begin{array}{l}\text { Anak-anak itu bermain di } \\
\text { halaman sekolah }\end{array}$ & $\begin{array}{l}\text { Sekolah tersebut memperoleh } \\
\text { sebuah penghargaan berupa } \\
\text { piagam }\end{array}$ \\
\hline $\mathbf{2 0}$ & $\begin{array}{l}\text { Farel membaca buku di } \\
\text { perpustakaan }\end{array}$ & $\begin{array}{l}\text { Ani rajin belajar diruangan } \\
\text { depan. }\end{array}$ & $\begin{array}{l}\text { Keindahan dapat dirasakan apabila } \\
\text { rumah kita selalu bersih. } \sqrt{ }\end{array}$ \\
\hline
\end{tabular}

The table above shows period punctuation error. The right use of the periods in the table above ismarked by a check $(\sqrt{ })$. The number of errors is a lot, which is 36 errors. The use of the period is very important in a sentence.Without the period punctuation, it cannot be called a sentence.It isa clause.

There are many errors in the use of prepositions in sentences produced by respondents. Here are the sentences that have errors in prepositions.

Table 8. Errors of kata depan (preposition)

\begin{tabular}{cll}
\hline No. & \multicolumn{1}{c}{ Incorrect } & \multicolumn{1}{c}{ Corret } \\
\hline 1 & Ani pergi kepasar & Ani pergi ke pasar \\
\hline 2 & Ani pergi kepasar membeli sayur-sayuran. & Ani pergi ke pasar membeli sayur-sayuran. \\
\hline 3 & Mereka pergi kepantai untuk berenang & Mereka pergi ke pantai untuk berenang \\
\hline 4 & $\begin{array}{l}\text { Agar dapat tidur nyenyak, Pak Nsir membeli } \\
\text { obat lelap diapotek }\end{array}$ & $\begin{array}{l}\text { Agar dapat tidur nyenyak, Pak Nsir membeli } \\
\text { obat lelap di apotek }\end{array}$ \\
\hline 5 & Tadi pagi Ibu memasak nasi didapur & Tadi pagi Ibu memasak nasi di dapur \\
\hline 6 & Saya sedang belajar dikamar. & Saya sedang belajar di kamar. \\
\hline 7 & $\begin{array}{l}\text { Kemarin Tina tidak turun kesekolah karena } \\
\text { sakit. }\end{array}$ & $\begin{array}{l}\text { Kemarin Tina tidak turun } \text { ke sekolah karena } \\
\text { sakit. }\end{array}$ \\
\hline 8 & Ani rajin belajar diruangan depan. & Ani rajin belajar di ruangan depan. \\
\hline
\end{tabular}

Errors in the prepositions $d i$ - and $k e$ - are due to misconceptions aboutthe function of preposition and affix. In writing, the prepositions should be separated from the word after it, while the affix is attached. The eight examples above are the incorrect use of the preposition of which it is attached to the word afterwards.

In addition to the errors above, there are also a diction selection error. Wrong selection of diction is due to the influence of local languages. As an example: Agar dapat tidur nyenyak, Pak Nsir membeli obat lelap diapotek. The 
word obat lelap is not commonly used in Indonesian.It should be obat tidur. Kemarin Tina tidak turun ke sekolah karena sakit. The word tidak turun is not commonly used in Indonesian.It should be tidak masuk or tidak berangkat. Making this error as an elementary school teachers is very concerning. Nurgiantoro (2005: 213) stated that children's language development is in line with the development of intellectual and personality aspects. By habituating students, especially in writing accordance with development intellectual and personality aspects, it is very possible for a person to be skilled in language both receptively and expressively. When the teacher, who is expected to give good writing habits, makes very basic linguistic mistakes then it will cause concern for the intellectual development of the children taught by that teacher. This is also in accordance with what Suyatinah stated (2005: 406) that the writing ability is very important for the teachers because it can help teachers teach their students a habit of writing proper Indonesian sentences according to the structure and sentence patterns in Indonesian language. The teacher is a very dominant factor in the education process and in the teaching and learning process (Sugiyono, 2002: 115).

\section{CONCLUSION}

The writing ability of Mahakam Ulu teachers, East Kalimantan is still lacking. This can be seen from the conformity of the sentences produced with the instruction given. The sentences that correspond to the instructions are $36.7 \%$, while the percentage of sentences that do not correspond to the instructions is $63.3 \%$. The instruction given was to make sentences with S-P-O, S-P-O-K, and K-S-P-O patterns. Sentences that correspond to the S-P-O pattern are $5 \%$, while the percentage of sentences that do not correspond to the S-P-O pattern is $45 \%$. Sentences that correspond to the SP-O-K pattern are $30 \%$, while the percentage of sentences that do not correspond to the S-P-O-K pattern is $70 \%$. Sentences that correspond to the K-S-P-O pattern are $25 \%$, while the percentage of sentences that do not correspond to the K-S-P-O pattern is $75 \%$. Errors made by teachers are errors in objek function, errors in keterangan function, errors in pelengkap function, errors in punctuations, prepositions, and dictions. The recommendations after this study were the provision of writing and literacy training to elementary school teachers.

\section{REFERENCES}

Brown, A. (2007). Teaching and learning communication, language and literacy. Landon: Paul Chapman Publishing.

Finoza, L. (2008). Komposisi Bahasa ndonesia. Jakarta: Diksi Insan Mulia.

Keraf, G. (1984). Diksi dan Gaya Bahasa. Jakarta: PT Gramedia Pustaka Utama.

Levinson, S. C. (1983). Pragmatics. New York: Cambridge Univerity Press.

Mustadi, A. (2014). Pengembangan model socioculture-based narrative untuk kompetensi menulis mata kuliah Bahasa Inggris di PGSD. Cakrawala Pendidikan, 32(2), 65-77. Retrieved from https://journal.uny.ac.id/index.ph p/cp/article/view/2587/pdf. 
Nurgiantoro, B. (2005). Tahapan perkembangan anak dan pemilihan bacaan sastra anak. Cakrawala Pendidikan, 24(1), 198-216. Retrieved from https://journal.uny.ac.id/index.ph $\mathrm{p} / \mathrm{cp} /$ article/view/369/pdf.

Riswanda. (2016). Kemampuan menulis akademik guru mata pelajaran nonbahasa di Jawa Barat. Cakrawala Pendidikan, 35(1), 63-75. Retrieved from https://journal.uny.ac.id/index.ph p/cp/article/view/9766/pdf.

Sugiyono. (2002). Pembinaan guru dengan sistem angka kredit. Cakrawala Pendidikan, 21(1), 115-133. Retrieved from https://journal.uny.ac.id/index.ph $\mathrm{p} / \mathrm{cp} /$ article/view/7473/pdf.

Suhardi and Setiawan, T. (1997). Sintaksis bahasa Indonesia. Jakarta: Universitas Terbuka.
Sulistiyono, T. (2014). Model koordinasi pengelolaan Gguru PNSdi Dinas Pendidikan Kota Yogyakarta pada era otonomi daerah. Cakrawala Pendidikan, 33(1), 112. Retrieved from https://journal.uny.ac.id/index.ph p/cp/article/view/1857.

Suyatinah. (2005). Peningkatan keefektifan pembelajaran menulis di kelas II sekolah dasar.Cakrawala Pendidikan, 24(3), 405-420.

Undang - Undang No. 2 Tahun 2013 tentang Pembentukan Kabupaten Mahakam Ulu Di Provinsi Kalimantan Timur. Lembaran Negara RI Tahun 2013, No. 5395. Jakarta: Sekretariat Negara. 